\title{
A New Participant in the Pathogenesis of Alcoholic Gastritis: Pyroptosis
}

\author{
Gang Lia Lei Zhu ${ }^{a} \quad$ Zhigang Cao ${ }^{b} \quad$ Jing Wang ${ }^{c}$ Fuxin Zhou ${ }^{d}$ \\ Xiuyun Wang ${ }^{\mathrm{e}}$ Xiaoguang $\mathrm{Li}^{\mathrm{f}}$ Gang Nie
}

aThe Second Affiliated Hospital of Harbin Medical University, Department of General Surgery, Harbin, bThe People Hospital of Daqing, Department of General Surgery, Daqing, 'Shanxi Province Cancer Hospital Institute, Tumor Molecular Targeted Therapy Wards, Taiyuan, dNO.404 Hospital of PLA, Department of Surgery, Weihai, eThe First Affiliated Hospital of Harbin Medical University, Department of Abdominal Ultrasound, Harbin, China, fJohns Hopkins University School of Medicine, Department of Cell Biology, Baltimore, USA

\section{Key Words}

Alcoholic gastritis • Pyroptosis • Caspase-1 1 IL-1ß • Ac-yvad-cmk

\begin{abstract}
Background/Aims: Alcohol abuse exerts deleterious effects on the internal organs of the body, and alcohol-related gastritis is a common disease for which prompt treatment is essential to prevent the condition from growing worse. However, the therapeutic methods have some adverse effects. Determining the pathogenic mechanisms of alcoholic gastritis is therefore essential. Methods: The MTT assay was developed in order to determine the optimal concentration of alcohol needed to treat gastric mucosal cells. The effects of alcohol on the gastric mucosal cells were determined by qRT-PCR and western blot. The release of IL-1 $\beta$ and IL-18 were determined by ELISA assay. The immunofluorescence assay was used to detect caspase-1 activation levels, while immunohistochemical assay and HE staining were performed to identify the effectiveness of the caspase- 1 inhibitor on alcoholic gastritis. The TUNEL assay was used to determine DNA fragmentation. Results: Here, we clarified that ethanol treatment could cause cell DNA damage, activate caspase- 1 , and promote the generation and release of IL-1 $\beta$ and IL-18. In other words, ethanol could induce pyroptosis. Interestingly, a caspase- 1 inhibitor could significantly suppress pyroptosis, decrease the release of inflammatory cytokines induced by ethanol, and cause no side effects in vivo and in vitro. Conclusion: Collectively, our results showed that pyroptosis is involved in the pathogenesis of alcohol-induced gastritis and that caspase- 1 inhibitor Ac-yvad-cmk could effectively decrease the damage caused by alcohol, making it a potentially promising agent for the treatment of alcoholic gastritis.




\section{Cellular Physiology Cell Physiol Biochem 2018;49:406-418 \begin{tabular}{l|l|l} 
DOI: 10.1159/000492902 & $\begin{array}{l}\text { O 2018 The Author(s). Published by S. Karger AG, Basel } \\
\text { wwww.karger.com/cpb }\end{array}$
\end{tabular}}

Li et al.: Pyroptosis Participates in Alcoholic Gastritis

\section{Introduction}

Drinking alcoholic beverages is a common feature of social gatherings, and ethanol is the main ingredient in all kinds of alcoholic beverages. The consumption of ethanol is related to approximately 60 different types of diseases [1-4]. It is well known that alcohol abuse may cause acute erosive hemorrhagic gastritis, and long-term drinking could cause stomach disorders and chronic atrophic gastritis [5-7]. In general, gastritis is mainly due to the imbalance between aggressive and defensive factors of the gastric mucosa, which causes a variety of issues, from local defects to active inflammation [8-11]. This kind of chronic inflammation is increasingly recognized to have significant tumor-promoting potential $[12,13]$. The precise regulation of inflammation progression is crucial for chronic inflammation disorders and for suppressing the depravation of pathogenetic conditions. Current therapeutic agents of gastritis are usually used to inhibit gastric acid secretion and to stimulate mucosal defense mechanisms [14-18]. However, these strategies generally fail due to hypersensitivity, gynecomastia, impotence, arrhythmia, and hematopoietic changes [19-21]. Therefore, exploring the mechanisms of gastritis and finding new therapeutic agents are vitally important.

Pyroptosis is a form of caspase-1- or caspase-11-dependent programmed cell death. In this process, a host cells recognize certain danger signals and produce cytokines, leading it to swell, burst, and ultimately die $[22,23]$. The main molecular characteristic of pyroptosis is the activation of caspase- 1 and the subsequent production and release of interleukin- $1 \beta$ (IL-1 $\beta$ ) and interleukin-18 (IL-18)[8]. Caspase-1 is an inflammatory caspase that is essential for canonical inflammasome-mediated pyroptosis and cytokine maturation [24]. Caspase-11 (also known as caspase-4 or -5 in humans), another inflammatory caspase, is the core component of non-canonical inflammasome. Caspase-11 directly acts as a receptor of cytosolic bacterial lipopolysaccharide (LPS) and is activated by binding to LPS[25]. Caspase-11 can trigger pyroptosis, but its effects on IL- $1 \beta$ and IL-18 maturation are indirect, because this process requires the NLRP3-dependent activation of caspase-1[26, 27]. Pyroptosis induces pathological inflammation, which is involved in the pathogenesis of multiple inflammatory diseases in several organs, including bowel [28], brain [29], heart [30] and kidney [31]. In gastritis, inflammation and mucosal cell death are also present. However, whether pyroptosis participates in the pathogenesis of gastritis remains unknown. Caspase- 1 is a key enzyme of pyroptosis, and we therefore mainly used the caspase- 1 inhibitor, Ac-yvad-cmk, to regulate pyroptosis [32-34]. The present study was thus designed to explore the role of pyroptosis in alcoholic gastritis.

\section{Materials and Methods}

\section{Cell culture and treatment}

GES-1 cells were obtained from ATCC. The cells were grown in RPMI-1640 (HyClone, Logan, UT, USA) containing 10\% fetal bovine serum (Biological Industries, Kibbutz Beit Haemek, Israel) and incubated at $37^{\circ} \mathrm{C}$ in humidified air with $5 \% \mathrm{CO}_{2}$. After seeding in a 96-well plate, the cells were treated with ethanol at concentrations of $0,0.5 \%, 1 \%, 2 \%, 4 \%, 8 \%$ and $16 \%$. An MTT assay was used to determine the cell viability. To explore the effects of ethanol and caspase-1 inhibitor $(100 \mu \mathrm{M})$, cells were treated with either ethanol or both ethanol and the caspase-1 inhibitor.

MTT assay

To measure the cell viability, $1 \times 10^{4}$ cells per well were seeded into a 96-well plate and treated as previously described. After treatment, $10 \mu \mathrm{l}$ MTT reagents $(0.5 \mathrm{mg} / \mathrm{ml})$ was added to each well and incubated for $4 \mathrm{~h}$ at $37^{\circ} \mathrm{C}$. The formazine granulars in the wells were dissolved with $150 \mu \mathrm{l}$ dimethyl sulphoxide (DMSO), and the absorbance at $570 \mathrm{~nm}$ was measured using a microplate reader. 


\section{Cellular Physiology Cell Physiol Biochem 2018;49:406-418 \begin{tabular}{ll|l} 
and Biochemistry & $\begin{array}{l}\text { DOI: 10.1159/000492902 } \\
\text { Published online: 24 August, } 2018\end{array}$ & $\begin{array}{l}\text { (c) } 2018 \text { The Author(s). Published by S. Karger AG, Basel } \\
\text { www.karger.com/cpb }\end{array}$
\end{tabular}}

Li et al.: Pyroptosis Participates in Alcoholic Gastritis

TUNEL staining

DNA damage was detected by terminal deoxynucleotidyl transferase-mediated dUTP nick-end labeling (TUNEL) staining using an apoptotic cell detection kit following the manufacturer's directions (Promega, Madison, WI, USA).

\section{HE staining}

Hematoxylin and eosin (HE) staining was used to observe the histological changes. Gastric tissues from mice or gastric cancer tissues and adjacent normal tissues from humans were fixed in $4 \%$ paraformaldehyde and embedded in paraffin. The samples were cut into 5 - $\mu$ m-thick sections and stained with HE.

\section{Immunofluorescence staining}

For immunofluorescence staining, cultured cells were fixed with $4 \%$ buffered paraformaldehyde. The cells were then washed in PBS and incubated with blocking solution (1\% BSA and 0.1\% Triton-X in PBS). Subsequently, the cells were incubated with primary antibodies against caspase- 1 overnight at $4^{\circ} \mathrm{C}$, followed by incubation with the secondary antibody (Invitrogen) for $1 \mathrm{~h}$ at room temperature. The nuclei were stained using 4',6-diamidino-2-phenylindole (DAPI; Beyotime, Shanghai, China) for 20 min at room temperature. The images were captured using a fluorescence microscope.

\section{Immunohistochemical staining}

For immunohistochemical analysis, frozen gastric section specimens were fixed with $4 \%$ buffered paraformaldehyde and embedded in paraffin. Specimens were dehydrated by an ascending series of ethanol and cleared with xylene. All sections were immunostained with primary antibodies against caspase-1, IL$1 \beta$ and IL-18 at $4^{\circ} \mathrm{C}$ overnight. After incubation with secondary antibodies, the sections were stained with diaminobenzidine.

\section{Enzyme-linked immunosorbent assay.}

The culture medium was collected for the measurement of IL-1 $\beta$ and IL-18 using an ELISA kit (uscnSEA064R and uscn-SEA563Ra) according to the manufacturer's instructions [35].

Mouse model of alcoholic gastritis

Male Kungming mice (25-30 g) were obtained from the Experimental Animal Center of Harbin Medical University. These mice were divided into three groups with five mice in each group. In the control and the ethanol groups, the mice were separately treated by gavage with saline or $2 \%$ ethanol $(20 \mathrm{ml} / \mathrm{kg} / \mathrm{d})$. In the caspase-1 inhibitor and ethanol group, mice were given $2 \%$ ethanol or $2 \%$ ethanol with caspase-1 inhibitor $(20 \mathrm{mg} / \mathrm{kg} / \mathrm{d})$ intraperitoneally. At $15 \mathrm{~d}$ after treatment, the mice were anesthetized and euthanized by cervical dislocation. The stomachs were harvested and rinsed with saline and used for the following detection. All experimental protocols were pre-approved by the Experimental Animal Ethics Committee of Harbin Medical University, China. The animals use was confirmed with the Guide for the Care and Use of Laboratory Animals published by the US National Institutes of Health (NIH Publication No. 85-23, revised 1996).

\section{qRT-PCR}

The total RNAs from cells or tissues were extracted using Trizol reagent (Invitrogen, Carlsbad, CA, USA). The extracted RNA was reverse-transcribed into double-strand cDNA with a reverse transcription kit (Toyobo, Osaka, Japan). Subsequently, the SYBR Green PCR Master Mix Kit (Applied Biosystems, Calif, USA) was used to quantify the mRNA expression level of caspase-1 and IL-1 $\beta$. Real time PCR was performed with the 7500 FAST real time PCR System (Applied Biosystems, CA, USA), using GAPDH as a control. The forward and reverse primer sequences for caspase-1 are 5'-TTTCCGCAAGGTTCGATTTTCA-3' and 5'-GGCATCTGCGCTCTACCATC-3', respectively. For IL-1 $\beta$, the forward primer was 5'-ATGATGGCTTATTACAGTGGCAA-3', and the reverse primer was 5'-GTCGGAGATTCGTAGCTGGA-3'. For IL-18, the forward primer was 5'-CAAGGAATTGTCTCCCAGTGC-3', and the reverse primer was 5'-CAGCCGCTTTAGCAGCCA-3'. 


\section{Cellular Physiology Cell Physiol Biochem 2018;49:406-418 \begin{tabular}{ll|l} 
and Biochemistry & $\begin{array}{l}\text { DOI: 10.1159/000492902 } \\
\text { Published online: 24 August, } 2018\end{array}$ & $\begin{array}{l}\text { (c) } 2018 \text { The Author(s). Published by S. Karger AG, Basel } \\
\text { www.karger.com/cpb }\end{array}$
\end{tabular}

Western blot analysis

The total protein was extracted from the cells using RIPA buffer (Thermo, Shanghai, China) containing phenylmethanesulfonylfluoride (PMSF) (Beyotime, China). The total protein concentrations were measured with a Bradford assay and Protein Assay Kit (Bio-Rad, Hercules, CA, USA). Thirty $\mu$ g of the protein lysate was subjected to sodium dodecyl sulfate-polyacrylamide gel electrophoresis (SDS-PAGE) and transferred onto PVDF membranes (Millipore, Billerica, Massachusetts, USA). The PVDF membranes were blocked with $5 \%$ BSA in $0.05 \%$ Tween 20 -TBS for 1 hour and incubated with the corresponding primary antibody. The mixtures were then diluted in blocking buffer overnight at $4^{\circ} \mathrm{C}$. Dilutions for primary antibodies were as follows: anti-caspase-1 (1:1, 000, Cell Signaling, 2225), anti-IL-1 $\beta$ and anti-IL-18 (1:400, Santa Cruz Biotech). After extensive washing with TBST, anti-rabbit IgG-HRP secondary antibody (1:5, 000, Santa Cruz Biotech) was added. Protein bands were visualized using the enhanced chemiluminescence technique with SuperSignal West Pico chemiluminescent substrate (Thermo Fisher Scientific, USA).

\section{Statistical Analysis}

All statistical analyses were performed using the SPSS 17.0 software (SPSS Inc., Chicago, IL, USA). One-way ANOVA was conducted for normally distributed data. All data were expressed as the mean \pm SD. Statistical significance was set at $P<0.05$.

\section{Results}

\section{Ethanol decreases cell viability in a concentration-dependent manner.}

Chronic alcohol consumption is highly associated with gastric disease and ulcers, which may progress to gastric cancer. Alcohol-induced gastric mucosal injury can be mediated by various cellular molecules such as cyclooxygenase (COX), lipoxygenase (LOX), cytokines, and oxygen-derived free radicals [36,37]. To clarify the pathogenesis of alcoholic gastritis, we first detected the effects of different concentrations of ethanol on the survival of GES-1 cells to define the optimal concentration of our assays. The cells were treated with ethanol at a concentration of $0,0.5 \%, 1 \%, 2 \%, 4 \%, 8 \%$ and $16 \%$. After 24 hours, viability detection of the cells showed the survival rate was decreased in a concentration-dependent manner (Fig. 1A).

Fig. 1. Ethanol treatment induced cell viability decreases and caspase-1 activation in GES-1 cells. A. Ethanol decreased the viability of GES-1 cells. B. Ethanol increased the mRNA expression of caspase-1. C. Immunofluorescence staining of caspase-1. D. Ethanol increased the protein expression of caspase-1. Data are representative of five independent experiments and represent the mean $\pm S D$. * $\mathrm{P}<0.05$ vs. 0 ethanol group.

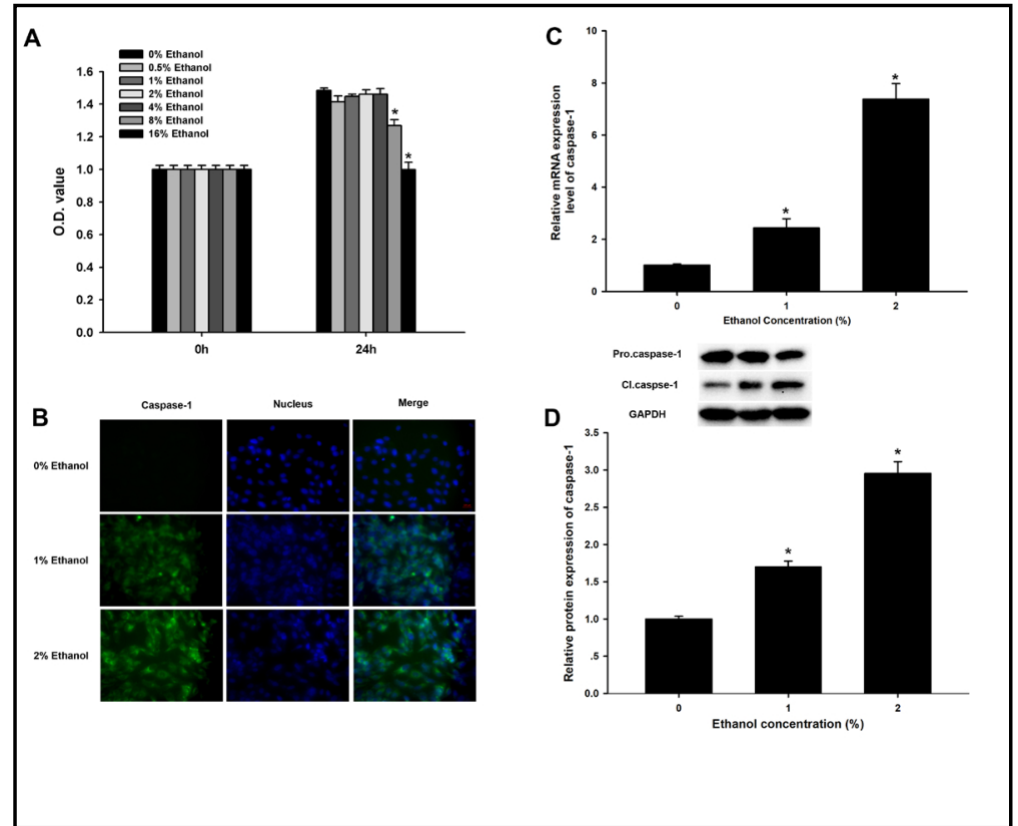


Ethanol induces
pyroptosis in gastric
mucosal cells.

Ethanol perfusion caused gastric mucosa damage [38] and induced oxidative stress and inflammation in the gastric tissues [39]. As part of the inflammation progress, pyroptosis is involved in many chronic diseases [40-43]. To clarify whether pyroptosis is included in gastritis pathogenic mechanisms, we detected the expression of caspase- 1 and inflammatory cytokines. In a preliminary experiment, we found that $1 \%$ and $2 \%$ ethanol could significantly increase the amount of active caspase- 1 with little effect on the viability of cells. Therefore, we chose concentrations of $1 \%$ and $2 \%$ for the following experiments. An immunofluorescence assay showed that caspase-1 co-localized with the nucleus in ethanol-treated cells. The greater the concentration of ethanol, the more cells that showed co-localization with the nucleus. However, in the normal cells, caspase-1 did not show this co-localization (Fig. 1B), suggesting that ethanol may activate caspase-1 in a concentration-dependent manner. To further clarify this phenomenon, we carried out real time PCR and western blot analysis to detect the mRNA and protein expression levels of caspase-1 (Fig. 1C, D). The results showed that both the mRNA and protein levels were increased in the ethanol-treated cells, especially in the $2 \%$ ethanol-treated cells.

DNA damage occurs during pyroptosis. TUNEL staining was used to further confirm the effect of ethanol on the cells. The results showed that the number of TUNEL positive cell increased after treatment with ethanol in a concentration dependent manner (Fig. 2).

We also detected the generation and release of IL-1 $\beta$ and IL-18, which are the downstream cytokines of caspase-1. GES- 1 cells were treated with either ethanol $(1 \%$ and $2 \%$ ) or solvent. An ELISA assay showed that ethanol treatment induced the release of IL-1 $\beta$ and IL-18 (Fig. 3A \& B). The mRNA and protein detection showed that ethanol could increase IL-1 $\beta$ and IL-18 expression levels in a concentration-dependent manner (Fig. 3C-F). These results indicated that ethanol $(1 \%$ and $2 \%)$ could induce pyroptosis in a concentrationdependent manner.

The inhibition of caspase-1 suppresses the inflammatory response induced by ethanol

We use siRNA and inhibitor to inhibit the function of caspase-1. Ac-yvad-cmk, a caspase- 1 inhibitor, could inhibit the activation of caspase- 1 . Cells were divided into five groups, including the control group, the si-NC group, the ethanol + si-NC group, the ethanol + si-caspase-1 group and the ethanol+caspase- 1 inhibitor group. Then, we carried out the immunofluorescence experiment (Fig. 4A). Compared with the group treated with ethanol group, si-caspase-1 or caspase- 1 inhibitor significantly decreased the co-localization of caspase- 1 and the nucleus, suggesting that si-caspase- 1 and Ac-yvad-cmk could suppress caspase- 1 activation. TUNEL assay revealed that the inhibition of caspase- 1 could protect against ethanol induced DNA damage (Fig. 4B \& C). The ELISA assay showed that the inhibition of caspase- 1 attenuated the release of IL-1 $\beta$ and IL-18 (Fig. 4D \& E). We then extracted the mRNA and protein and carried out real time PCR and western blot assays. Our results were consistent with the immunofluorescence observations. si-caspase- 1 and Acyvad-cmk significantly suppressed the caspase-1, IL-1 $\beta$ and IL-18 mRNA expression levels (Fig. 4F-H), as well as the protein expression levels (Fig. 4I-L). These data indicated that the caspase- 1 inhibitor could inhibit pyroptosis caused by ethanol, thereby weakening the inflammation responses. 
Cellular Physiology Cell Physiol Biochem 2018;49:406-418

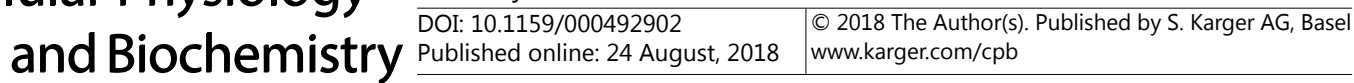

Li et al.: Pyroptosis Participates in Alcoholic Gastritis

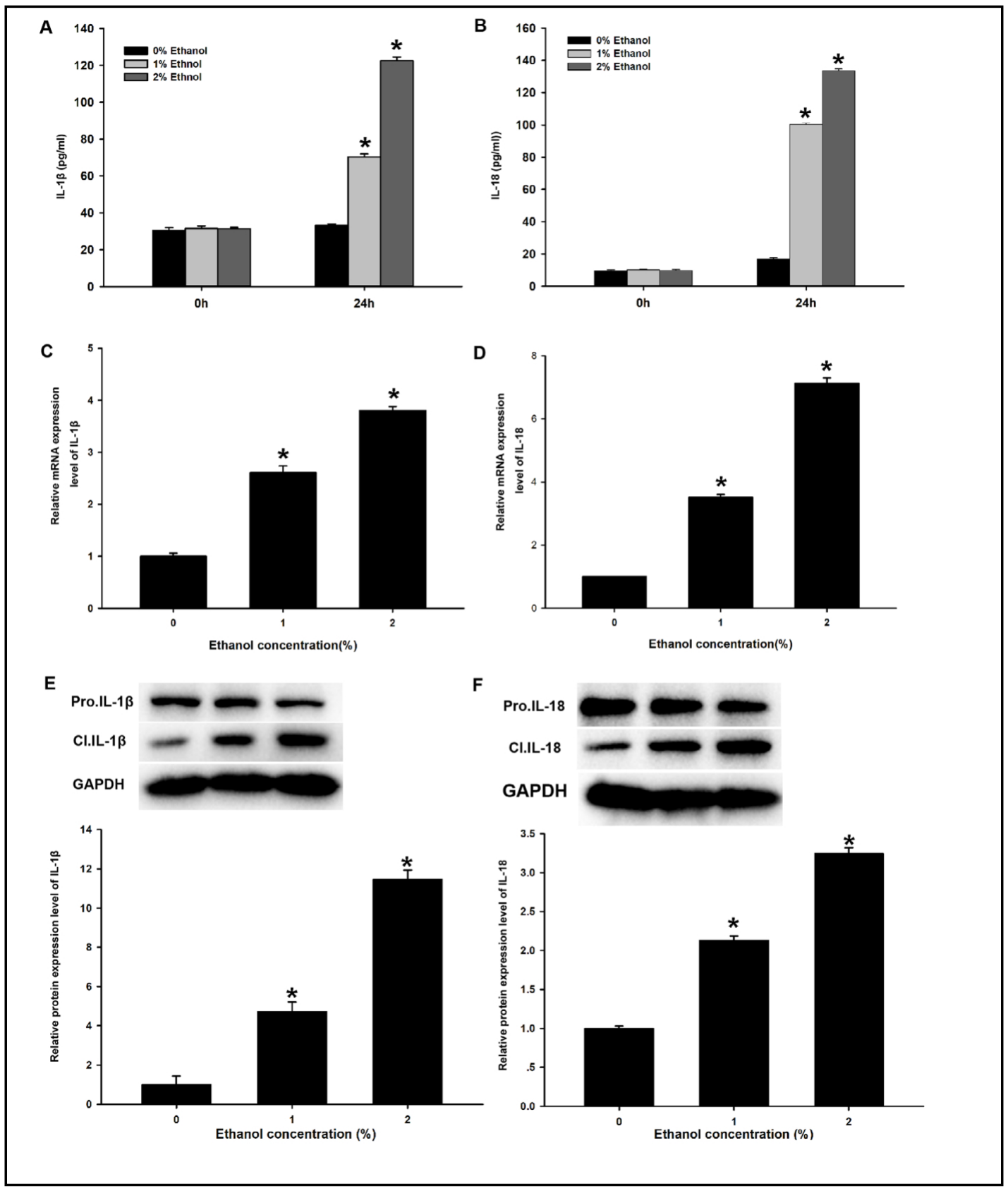

Fig. 3. Ethanol promotes the generation and release of IL $-1 \beta$ and IL-18. A \& B. The release of IL $-1 \beta$ and IL18. C \& D. The mRNA expression of IL $-1 \beta$ and IL-18. E \& F. The protein expression of IL - $1 \beta$ and IL-18. Data are representative of five independent experiments and represent the mean \pm SD. ${ }^{*} \mathrm{P}<0.05$ vs. 0 ethanol group. 


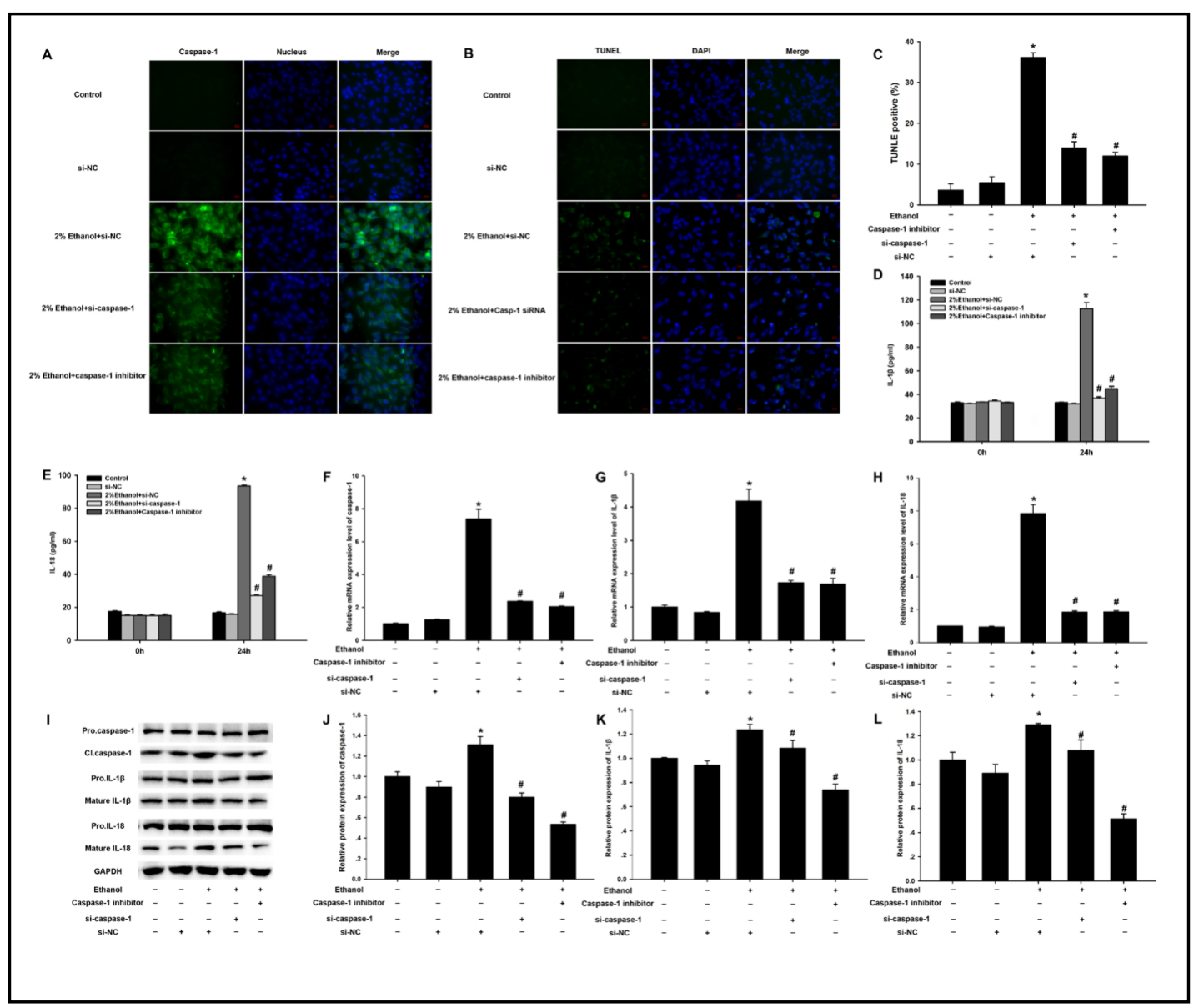

Fig. 4. Caspase-1 knockdown attenuates the GES-1 cell injury induced by ethanol. A. Immunofluorescence staining of caspase-1. B. DNA damage was detected using the TUNEL assay in GES-1 cells. C-E. The mRNA expression of caspase-1, IL $-1 \beta$ and IL-18. F. Representative western blot bands. G-J. The protein expression of caspase-1, IL $-1 \beta$ and IL-18. Data are representative of five independent experiments and represent the mean $\pm \mathrm{SD}$. ${ }^{*} \mathrm{P}<0.05$ vs. control group. \# $\mathrm{P}<0.05$ vs. ethanol group.

Caspase-1 inhibitor protects against alcoholic gastritis in mice without obvious side effects

To explore the therapeutic potential of the caspase-1 inhibitor in vivo, mice were divided into three groups, including the control group, the ethanol group and the ethanol+caspase- 1 inhibitor group. We isolated the gastric epithelial tissues of these three groups for HE staining and detected inflammatory cell evasion level in these three groups. Our results showed that a significant decrease in mouse gastric mucosal inflammation was observed in the ethanol and Ac-yvad-cmk treated group, compared with the ethanol treated group. This decrease was almost equal to the normal group (Fig. $5 \mathrm{~A}$ ). Next, we detected caspase-1, IL-1 $\beta$ and IL-18 expression via immunohistochemical assays using the gastric epithelial tissues of these three groups. The results showed that caspase-1, IL-1 $\beta$ and IL-18 were activated in the ethanol-treated groups, and the caspase-1 inhibitor Ac-yvad-cmk significantly decreased the activation levels (Fig. 5B-D). To further clarify the role of the caspase- 1 inhibitor in suppressing the inflammatory response, we extracted the mRNA from gastric tissues. The real time PCR results showed that caspase- 1 inhibitor significantly decreased the elevation of the caspase-1, IL-1 $\beta$ and IL-18 mRNA expression levels induced by ethanol (Fig. 5E-G). Next, we detected the protein expression level of these three groups. The results showed that the caspase- 1 inhibitor decreased the translation levels of caspase-1, IL-1 $\beta$ and IL-18 (Fig. $5 \mathrm{H}-\mathrm{K})$. Importantly, the caspase- 1 inhibitor showed no significant adverse effects on gastric tissues form mice and GES-1 cells (Fig. 6).

\section{KARGER}


A

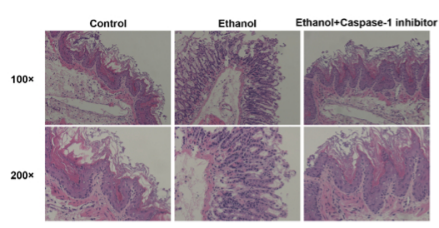

B
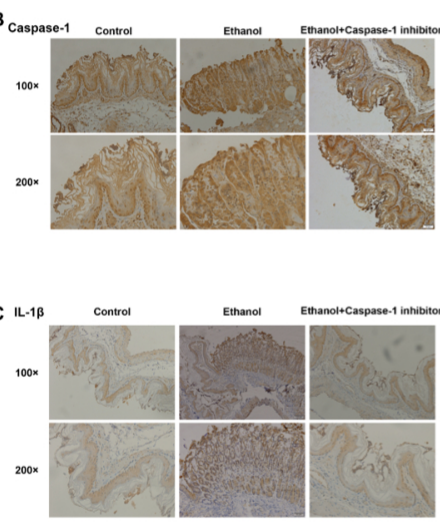

D LL-18

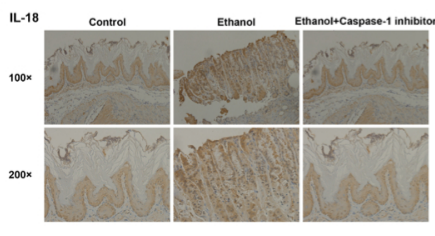

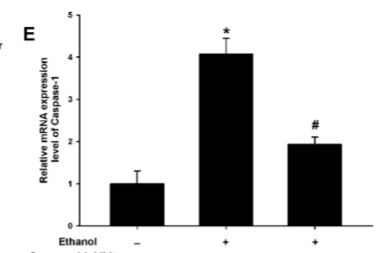

F
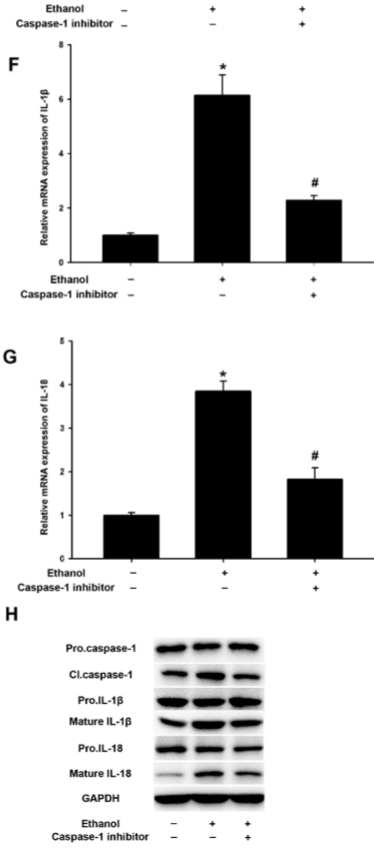
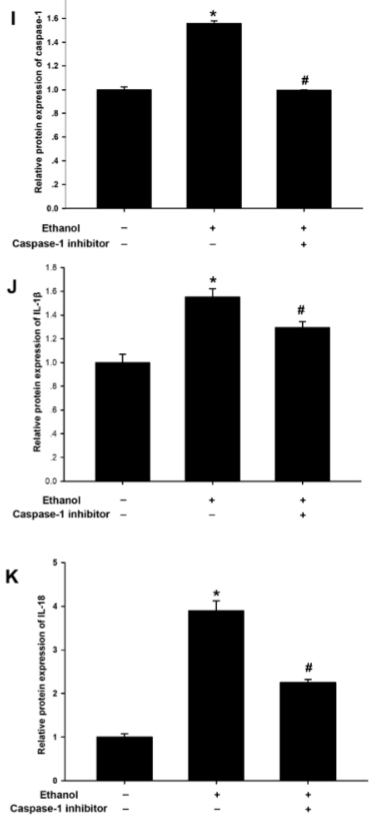

Fig. 5. The caspase- 1 inhibitor attenuates the gastric injury induced by ethanol in mice. A. Gastric histopathology of mice was analyzed with hematoxylin and eosin (HE) staining (magnification, 100×). B-D. Immunohistomical staining of caspase-1, IL-1 $\beta$ and IL-18 in gastric tissues from mice (magnification, 40×). E-G. The mRNA expression level of caspase-1, IL $-1 \beta$ and IL-18. H. Representative western blot bands. I-K. The protein expression levels of caspase-1, IL $-1 \beta$ and IL-18. Data are representative of five independent experiments and represent the mean \pm SD. ${ }^{*} \mathrm{P}<0.05$ vs. the control group. \# $\mathrm{P}<0.05$ vs. the ethanol group.

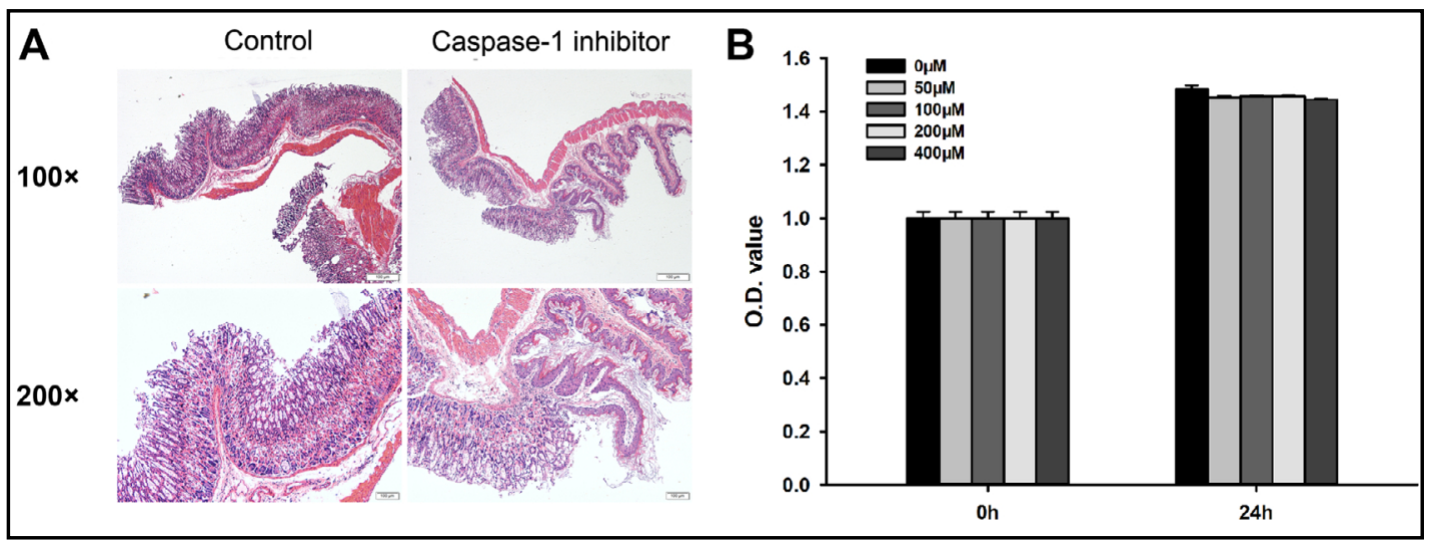

Fig. 6. The caspase-1 inhibitor showed no significant adverse effects on gastric tissues form mice and GES-1 cells. A. The histological characteristic of gastric tissues from mice treated with the caspase-1 inhibitor. B. The viability of GES-1 cells treated with the caspase-1 inhibitor. Data are representative of five independent experiments and represent the mean \pm SD. 


\section{Cellular Physiology

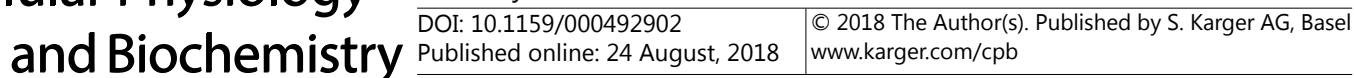

Fig. 7. Caspase-1, IL-1 $\beta$ and IL-18 were upregulated in human gastric cancer tissues. A-C. Immunohistochemical staining of caspase-1, IL-1 $\beta$ and IL-18 in gastric cancer tissues and adjacent normal tissues (magnification, 20x). D. The mRNA expression levels of caspase- $1, \mathrm{I}-1 \beta$, and IL18. E. Representative western blot bands. F-H. The protein expression levels of caspase-1, IL $-1 \beta$ and IL-18. Data are representative of five independent experiments and represent the mean \pm SD. ${ }^{*} \mathrm{P}<0.05$ vs. Normal group.

Pyroptosis is included in gastric cancer

Previous studies have shown that atrophic gastritis is a probable forerunner of gastric cancer [44]. Since pyroptosis plays an important role in gastritis induced by ethanol, we next detected the activation levels of caspase- 1, IL-1 $\beta$ and IL-18 in gastric cancer cells to determine if pyroptosis was involved in gastric cancer progression. We carried out an immunohistomical assay to detect the caspase- 1 expression levels using

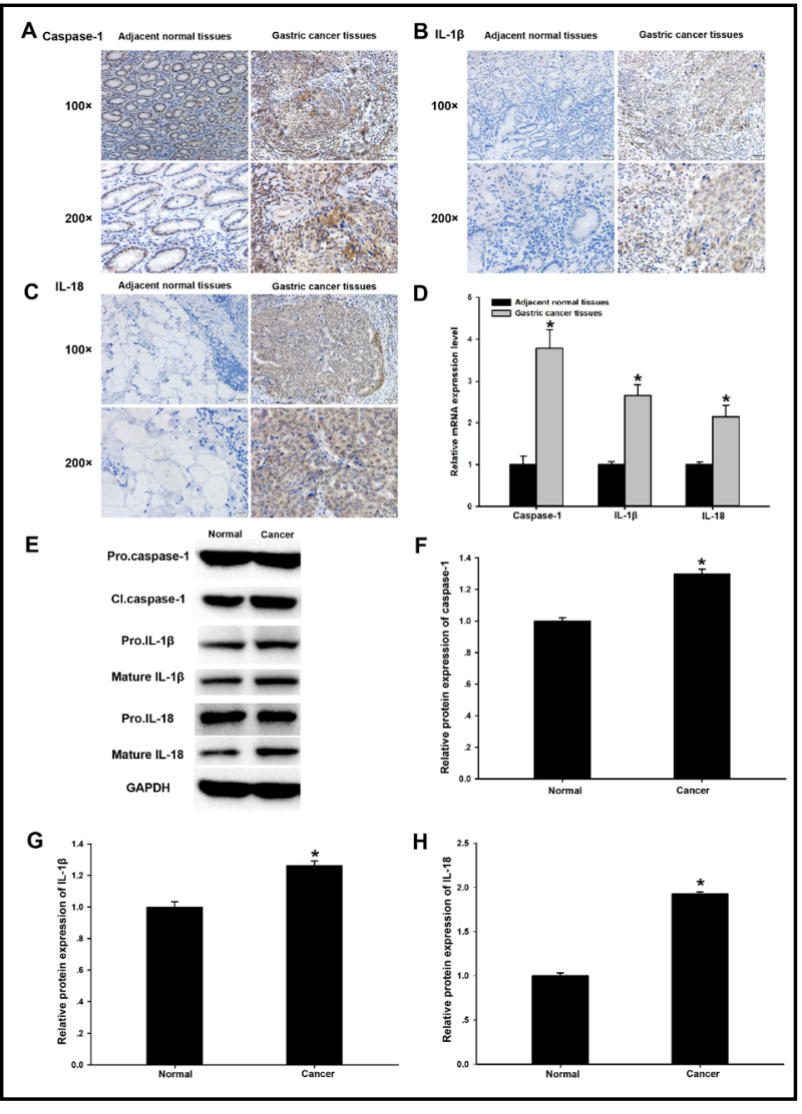
the gastric cancer tissues and adjacent normal tissues, and a significant increase in the caspase- 1 and IL-1 $\beta$ and IL-18 expression levels was observed in the gastric cancer tissues compared with the adjacent normal tissues (Fig. 7A-C). We then detected the transcription levels of caspase-1, IL-1 $\beta$ and IL-18, and our results showed that the caspase- $1, \mathrm{IL}-1 \beta$ and IL-18 mRNA expression levels were upregulated in gastric cancer tissues compared to the adjacent normal tissues (Fig. 7D). Furthermore, the protein expression of caspase-1, IL-1 $\beta$ and IL-18 were higher in the cancer tissues than in the non-tumor tissues (Fig. 7E-H). Taken together, these results suggest that pyroptosis plays a role in the gastric cancer progression.

\section{Discussion}

Chronic gastritis is a multistep, progressive and life-long inflammatory process [4549], and the available treatments for this disease remain deficient. Increased levels of inflammation with the release of large amounts of cytokines are the main features of gastritis [50-53]. It has become clear that bacteria have caused gastritis in the overwhelming majority of the cases recorded since 1982[54]. However, before that, studies have shown that alcohol causes chronic gastritis and the severity of the mucosal lesion is directly related to the duration of excess drinking $[55,56]$. Here, we showed that ethanol could induce pyroptosis in GES- 1 cells, and this was characterized by DNA damage, the activation of caspase- 1 and the release of IL- $1 \beta$ and IL-18. These changes were reduced by treatment with a caspase- 1 inhibitor. Pyroptosis is a highly inflammatory form of programmed cell death, which is triggered by caspase- 1 activation and associated with pro-inflammatory cytokine production. Accumulating evidence has revealed the important role of pyroptosis in various pathophysiological conditions, including microbial infection, nervous diseases and heart diseases [57-60]. 


\section{Cellular Physiology Cell Physiol Biochem 2018;49:406-418 \begin{tabular}{l|l|l} 
DOI: 10.1159/000492902 & $\begin{array}{l}\text { O 2018 The Author(s). Published by S. Karger AG, Basel } \\
\text { wwww.karger.com/cpb }\end{array}$
\end{tabular} \\ Li et al.: Pyroptosis Participates in Alcoholic Gastritis}

Our study identified the involvement of pyroptosis in the pathogenesis of alcoholic gastritis. We established a model for alcoholic gastritis. Histopathological and molecular biological detection all suggested that ethanol could induce pyroptosis, as characterized by an exaggerated inflammatory response, caspase- 1 activation and pro-inflammatory factor release. Remarkably, caspase- 1 inhibitor could significantly block pyroptosis, alleviate the inflammatory responses and ameliorate the gastric injury induced by ethanol accumulation. Previous studies have shown that the caspase-1 inhibitor Ac-yvad-cmk protects against acute gastric injury in mice by affecting the NLRP3 inflammasome and attenuating inflammatory processes and apoptosis [34]. Ac-yvad-cmk is an efficient caspase- 1 inhibitor and is involved in many other diseases [61-65]. This finding is consistent with our results. Importantly, there was no adverse effect of this inhibitor on the effective dosage in vivo and in vitro. Furthermore, we clarified that pyroptosis was also involved in the gastric cancer progression, which suggested that the caspase-1 inhibitor, Ac-yvad-cmk, may be a potential agent for the treatment of gastric-related diseases.

In summary, three important findings are presented in the current study. First, caspase1-induced pyroptosis was found to be involved in the pathogenesis of alcoholic gastritis. Second, treatment with a caspase-1 inhibitor alleviated ethanol-induced gastric injury. Lastly, the caspase-1 inhibitor, Ac-yvad-cmk, might be an effective agent for the protection against alcoholic gastritis. These findings will improve our understanding of the role of pyroptosis in alcoholic gastritis and provide a new therapeutic approach for the management of alcoholic gastritis and other diseases associated with pyroptosis.

\section{Conclusion}

In summary, the present study provides convincing evidence that pyroptosis was involved in the pathogenesis of ethanol induced gastritis. The caspase- 1 inhibitor could inhibit ethanol-induced gastritis.

\section{Disclosure Statement}

The authors declare to have no conflict of interests.

\section{References}

-1 Kato H, Naiki-Ito A, Naiki T, Suzuki S, Yamashita Y, Sato S, Sagawa H, Kato A, Kuno T, Takahashi S: Connexin 32 dysfunction promotes ethanol-related hepatocarcinogenesis via activation of Dusp1-Erk axis. Oncotarget 2016;7:2009-2021.

-2 Richey L, Doremus-Fitzwater TL, Buck HM, Deak T: Acute illness-induced behavioral alterations are similar to those observed during withdrawal from acute alcohol exposure. Pharmacol Biochem Behav 2012;103:284-294.

3 Ratna A, Mandrekar P: Alcohol and Cancer: Mechanisms and Therapies. Biomole 2017;7:61.

-4 Teunissen HA, Spijkerman R, Cohen GL, Prinstein MJ, Engels RCME, Scholte RHJ: An experimental study on the effects of peer drinking norms on adolescents' drinker prototypes. Addict Behav 2014;39:85-93.

-5 Yang C-X, Matsuo K, Wang Z-M, Tajima K: Phase I/II enzyme gene polymorphisms and esophageal cancer risk: A meta-analysis of the literature. World J Gastroenterol 2005;11:2531-2538.

-6 Jeon W-Y, Lee M-Y, Shin I-S, Jin SE, Ha H: Curcuma aromatica Water Extract Attenuates EthanolInduced Gastritis via Enhancement of Antioxidant Status. Evid Based Complement Alternat Med 2015;2015:582496.

7 Park J-H, Jang K-J, Kim C-H, Kim J-H, Kim Y-K, Yoon H-M: Ganoderma Lucidum Pharmacopuncture for Teating Ethanol-induced Chronic Gastric Ulcers in Rats. J Pharmacopuncture 2015;18:72-78. 


\section{Cellular Physiology Cell Physiol Biochem 2018;49:406-418 \begin{tabular}{ll|l} 
DOI: 10.1159/000492902 & $\begin{array}{l}\text { O } 2018 \text { The Author(s). Published by S. Karger AG, Basel } \\
\text { www.karger.com/cpb }\end{array}$ \\
\hline and Biochemistry
\end{tabular}}

Li et al.: Pyroptosis Participates in Alcoholic Gastritis

8 Ahluwalia A, Baatar D, Jones MK, Tarnawski AS: Novel mechanisms and signaling pathways of esophageal ulcer healing: the role of prostaglandin EP2 receptors, cAMP, and pCREB. Am J Physiol Gastrointest Liver Physiol 2014;307:G602-G610.

-9 Huang Y, Wang Q-l, Cheng D-d, Xu W-t, Lu N-h: Adhesion and Invasion of Gastric Mucosa Epithelial Cells by Helicobacter pylori. Front Cell Infect Microbiol 2016;6:159.

$>10$ Sipponen P, Maaroos H-I: Chronic gastritis. Scand J Gastroenterol 2015;50:657-667.

11 Wen Z, Li X, Lu Q, Brunson J, Zhao M, Tan J, Wan C, Lei P: Health related quality of life in patients with chronic gastritis and peptic ulcer and factors with impact: a longitudinal study. BMC Gastroenterol 2014;14:149-149.

-12 Yoshizaki T, Schenk S, Imamura T, Babendure JL, Sonoda N, Bae EJ, Oh DY, Lu M, Milne JC, Westphal C, Bandyopadhyay G, Olefsky JM: SIRT1 inhibits inflammatory pathways in macrophages and modulates insulin sensitivity. Am J Physiol-Endoc M 2010;298:E419-E428.

-13 Zhang J, Ren J, Hao S, Ma F, Xin Y, Jia W, Sun Y, Liu Z, Yu H, Jia J, Li W: MiRNA-491-5p inhibits cell proliferation, invasion and migration via targeting JMJD2B and serves as a potential biomarker in gastric cancer. Am J Transl Res 2018;10:525-534.

14 Zhou Q Yan X-F, Zhang Z-M, Pan W-S, Zeng S: Rational prescription of drugs within similar therapeutic or structural class for gastrointestinal disease treatment: Drug metabolism and its related interactions. World J Gastroenterol 2007;13:5618-5628.

15 Yamada S, Kawakami T, Nakatsugawa Y, Suzuki T, Fujii H, Tomatsuri N, Nakamura H, Sato H, Okuyama Y, Kimura H, Yoshida N: Usefulness of vonoprazan, a potassium ion-competitive acid blocker, for primary eradication of Helicobacter pylori. World J Gastrointest Pharmacol Ther 2016;7:550-555.

-16 Mukaisho K-i, Hagiwara T, Nakayama T, Hattori T, Sugihara H: Potential mechanism of corpus-predominant gastritis after PPI therapy in Helicobacter pylori-positive patients with GERD. World J Gastroenterol 2014;20:11962-11965.

17 Hijaz NM, Septer SS, Degaetano J, Attard TM: Clinical outcome of pediatric collagenous gastritis: Case series and review of literature. World J Gastroenterol 2013;19:1478-1484.

18 Nasser SC, Slim M, Nassif JG, Nasser SM: Influence of proton pump inhibitors on gastritis diagnosis and pathologic gastric changes. World J Gastroenterol 2015;21:4599-4606.

19 Halim SZ, Zakaria ZA, Omar MH, Mohtarrudin N, Wahab IRA, Abdullah MNH: Synergistic gastroprotective activity of methanolic extract of a mixture of Melastoma malabathricum and Muntingia calabura leaves in rats. BMC Complement Altern Med 2017;17:488.

20 Lin C-J, Liao W-C, Chen Y-A, Lin H-J, Feng C-L, Lin C-L, Lin Y-J, Kao M-C, Huang M-Z, Lai C-H, Kao C-H: Statin Therapy Is Associated with Reduced Risk of Peptic Ulcer Disease in the Taiwanese Population. Front Pharmacol 2017;8:210.

21 Moghadamtousi SZ, Rouhollahi E, Karimian H, Fadaeinasab M, Abdulla MA, Kadir HA: Gastroprotective activity of Annona muricata leaves against ethanol-induced gastric injury in rats via Hsp70/Bax involvement. Drug Des Devel Ther 2014;8:2099-2111.

-22 Fuchs Y, Steller H: Programmed Cell Death in Animal Development and Disease. Cell 2011;147:742-758.

-23 Jorgensen I, Miao EA: Pyroptotic cell death defends against intracellular pathogens. Immunol Rev 2015;265:130-142.

24 Conforti-Andreoni C, Ricciardi-Castagnoli P, Mortellaro A: The inflammasomes in health and disease: from genetics to molecular mechanisms of autoinflammation and beyond. Cell Mol Immunol 2011;8:135-145.

25 Rongvaux A, Jackson R, Harman CCD, Li T, West AP, de Zoete MR, Wu Y, Yordy B, Lakhani SA, Kuan C-Y, Taniguchi T, Shadel GS, Chen ZJ, Iwasaki A, Flavell RA: Apoptotic caspases prevent the induction of type I interferons by mitochondrial DNA. Cell 2014;159:1563-1577.

26 Storek KM, Monack DM: Bacterial recognition pathways that lead to inflammasome activation. Immunol Rev 2015;265:112-129.

27 Thurston TLM, Matthews SA, Jennings E, Alix E, Shao F, Shenoy AR, Birrell MA, Holden DW: Growth inhibition of cytosolic Salmonella by caspase-1 and caspase-11 precedes host cell death. Nat Commun 2016;7:13292.

-28 Kast RE: The role of interleukin-18 in glioblastoma pathology implies therapeutic potential of two old drugs-disulfiram and ritonavir. Chin J Cancer 2015;34:11. 


\section{Cellular Physiology Cell Physiol Biochem 2018;49:406-418 \begin{tabular}{ll|l} 
DOI: 10.1159/000492902 & $\begin{array}{l}\text { O } 2018 \text { The Author(s). Published by S. Karger AG, Basel } \\
\text { www.karger.com/cpb }\end{array}$ \\
and Biochemistry
\end{tabular}}

Li et al.: Pyroptosis Participates in Alcoholic Gastritis

29 Ramos HJ, Lanteri MC, Blahnik G, Negash A, Suthar MS, Brassil MM, Sodhi K, Treuting PM, Busch MP, Norris PJ, Gale M: IL-1 $\beta$ Signaling Promotes CNS-Intrinsic Immune Control of West Nile Virus Infection. PLoS Pathog 2012;8:e1003039.

-30 Jeyabal P, Thandavarayan RA, Joladarashi D, Babu SS, Krishnamurthy S, Bhimaraj A, Youker KA, Kishore R, Krishnamurthy P: MicroRNA-9 inhibits hyperglycemia induced cardiac pyroptosis in human ventricular cardiomyocytes by targeting ELAVL1. Biochem Biophys Res Commun 2016;471:423-429.

-31 Dong B, Zhou H, Han C, Yao J, Xu L, Zhang M, Fu Y, Xia Q: Ischemia/Reperfusion-Induced CHOP Expression Promotes Apoptosis and Impairs Renal Function Recovery: The Role of Acidosis and GPR4. PLoS ONE 2014;9:e110944.

-32 Choulaki C, Papadaki G, Repa A, Kampouraki E, Kambas K, Ritis K, Bertsias G, Boumpas DT, Sidiropoulos P: Enhanced activity of NLRP3 inflammasome in peripheral blood cells of patients with active rheumatoid arthritis. Arthritis Res Ther 2015;17:257.

-33 Zhang F, Wang L, Wang J-j, Luo P-f, Wang X-t, Xia Z-f: The caspase-1 inhibitor AC-YVAD-CMK attenuates acute gastric injury in mice: involvement of silencing NLRP3 inflammasome activities. Sci Rep 2016;6:24166.

34 Wu B, Ma Q Khatibi N, Chen W, Sozen T, Cheng O, Tang J: Ac-YVAD-CMK Decreases Blood-Brain Barrier Degradation by Inhibiting Caspase-1 Activation of Interleukin-1 $\beta$ in Intracerebral Hemorrhage Mouse Model. Transl Stroke Res 2010;1:57-64.

-35 Fang C, Xie L, Liu C, Fu C, Ye W, Liu H, Zhang B: Berberine ameliorates neonatal necrotizing enterocolitis by activating the phosphoinositide 3-kinase/protein kinase B signaling pathway. Exp Ther Med 2018;15:35303536.

-36 Tarnawski AS, Ahluwalia A, Jones MK: Increased susceptibility of aging gastric mucosa to injury: The mechanisms and clinical implications. World J Gastroenterol 2014;20:4467-4482.

-37 Lee H-J, Ock CY, Kim S-J, Hahm K-B: Heat Shock Protein: Hard Worker or Bad Offender for Gastric Diseases. Int J Proteomics 2010;2010:259163.

38 Ning J-W, Lin G-B, Ji F, Xu J, Sharify N: Preventive effects of geranylgeranylacetone on rat ethanol-induced gastritis. World J Gastroenterol 2012;18:2262-2269.

-39 Davies SS, Zhang LS: Reactive Carbonyl Species Scavengers-Novel Therapeutic Approaches for Chronic Diseases. Curr Pharmacol Rep 2017;3:51-67.

40 Maltez VI, Tubbs AL, Cook KD, Aachoui Y, Falcone EL, Holland SM, Whitmire JK, Miao EA: Inflammasomes coordinate pyroptosis and natural killer cell cytotoxicity to clear infection by a ubiquitous environmental bacterium. Immunity 2015;43:987-997.

41 Conley SM, Abais JM, Boini KM, Li P-L: Inflammasome Activation in Chronic Glomerular Diseases. Curr Drug Targets 2017;18:1019-1029.

42 Lebeaupin C, Proics E, de Bieville CHD, Rousseau D, Bonnafous S, Patouraux S, Adam G, Lavallard VJ, Rovere C, Le Thuc O, Saint-Paul MC, Anty R, Schneck AS, Iannelli A, Gugenheim J, Tran A, Gual P, Bailly-Maitre B: ER stress induces NLRP3 inflammasome activation and hepatocyte death. Cell Death Dis 2015;6:e1879.

43 Boini KM, Xia M, Abais JM, Li G, Pitzer AL, Gehr TWB, Zhang Y, Li P-L: Activation of Inflammasomes in Podocyte Injury of Mice on the High Fat Diet: Effects of ASC Gene Deletion and Silencing. Biochim Biophys Acta 2014;1843:836-845.

44 Choi YJ, Kim N: Gastric cancer and family history. Korean J Intern Med 2016;31:1042-1053.

45 Rugge M: Secondary prevention of gastric cancer. Gut 2007;56:1646-1647.

-46 Muszyński J, Ziółkowski B, Kotarski P, Niegowski A, Górnicka B, Bogdańska M, Ehrmann-Jóśko A, Zemlak M, Młynarczyk-Bonikowska B, Siemińska J: Gastritis - facts and doubts. Prz Gastroenterol 2016;11:286-295.

47 Buzás GM: Metabolic consequences of Helicobacter pylori infection and eradication. World J Gastroenterol 2014;20:5226-5234.

48 Vohlonen I, Pukkala E, Malila N, Härkönen M, Hakama M, Koistinen V, Sipponen P: Risk of gastric cancer in Helicobacter pylori infection in a 15-year follow-up. Scand J Gastroenterol 2016;51:1159-1164.

-49 Piazuelo MB, Camargo MC, Mera RM, Delgado AG, Peek RM, Correa H, Schneider BG, Sicinschi LA, Mora Y, Bravo LE, Correa P: Eosinophils and mast cells in chronic gastritis: Possible implications in carcinogenesis. Hum Pathol 2008;39:1360-1369.

50 Bi W-P, Man H-B, Man M-Q: Efficacy and safety of herbal medicines in treating gastric ulcer: A review. World J Gastroenterol 2014;20:17020-17028. 


\section{Cellular Physiology Cell Physiol Biochem 2018;49:406-418 \begin{tabular}{l|l} 
DOI: 10.1159/000492902 & $\begin{array}{l}\text { O 2018 The Author(s). Published by S. Karger AG, Basel } \\
\text { www.karger.com/cpb }\end{array}$
\end{tabular} \\ Li et al.: Pyroptosis Participates in Alcoholic Gastritis}

51 Kan J, Hood M, Burns C, Scholten J, Chuang J, Tian F, Pan X, Du J, Gui M: A Novel Combination of Wheat Peptides and Fucoidan Attenuates Ethanol-Induced Gastric Mucosal Damage through Anti-Oxidant, AntiInflammatory, and Pro-Survival Mechanisms. Nutrients 2017;9:978.

52 Kim JW, Lee S-Y, Kim JH, Sung I-K, Park HS, Shim C-S, Han HS: Nodule Regression in Adults With Nodular Gastritis. Gastroent Res 2015;8:296-302.

-53 Philipson CW, Bassaganya-Riera J, Viladomiu M, Kronsteiner B, Abedi V, Hoops S, Michalak P, Kang L, Girardin SE, Hontecillas R: Modeling the Regulatory Mechanisms by Which NLRX1 Modulates Innate Immune Responses to Helicobacter pylori Infection. PLoS ONE 2015;10:e0137839.

54 Pagkalos VA, Moschandreas J, Kiriakakis M, Roussomoustakaki M, Kafatos A, Kouroumalis E: Fatty acid composition of subcutaneous adipose tissue and gastric mucosa: is there a relation with gastric ulceration? BMC Gastroenterol 2009;9:9-9.

55 Roberts DM: Chronic gastritis, alcohol, and non-ulcer dyspepsia. Gut 1972;13:768-774.

56 Ibrahim MY, Hashim NM, Dhiyaaldeen SM, Al-Obaidi MM, El-Ferjani RM, Adam H, Alkotaini B, Batran RA, Ali HM: Acute Toxicity and Gastroprotection Studies of a New Schiff Base Derived Manganese (II) Complex against $\mathrm{HCl}$ /Ethanol-Induced Gastric Ulcerations in Rats. Sci Rep 2016;6:26819.

57 Doitsh G, Galloway NLK, Geng X, Yang Z, Monroe KM, Zepeda O, Hunt PW, Hatano H, Sowinski S, MuñozArias I, Greene WC: Pyroptosis drives CD4 T-cell depletion in HIV-1 infection. Nature 2014;505:509-514.

58 Adamczak SE, de Rivero Vaccari JP, Dale G, Brand FJ, Nonner D, Bullock M, Dahl GP, Dietrich WD, Keane RW: Pyroptotic neuronal cell death mediated by the AIM2 inflammasome. J Cereb Blood Flow Metab 2014;34:621-629.

59 Kölling M, Genschel C, Kaucsar T, Hübner A, Rong S, Schmitt R, Sörensen-Zender I, Haddad G, Kistler A, Seeger H, Kielstein JT, Fliser D, Haller H, Wüthrich R, Zörnig M, Thum T, Lorenzen J: Hypoxia-induced long non-coding RNA Malat1 is dispensable for renal ischemia/reperfusion-injury. Sci Rep 2018;8:3438.

-60 Hou Z, Xu X, Fu X, Tao S, Zhou J, Liu S, Tan D: HBx-related long non-coding RNA MALAT1 promotes cell metastasis via up-regulating LTBP3 in hepatocellular carcinoma.Am J Cancer Res 2017;7:845-856.

61 Shetty AK, Hattiangady B, Rao MS, Shuai B: Deafferentation Enhances Neurogenesis in the Young and Middle Aged Hippocampus but not in the Aged Hippocampus. Hippocampus 2011;21:631-646.

62 Osuka A, Hanschen M, Stoecklein V, Lederer JA: A PROTECTIVE ROLE FOR INFLAMMASOME ACTIVATION FOLLOWING INJURY. Shock (Augusta, Ga.) 2012;37:47-55.

63 Motani K, Kushiyama H, Imamura R, Kinoshita T, Nishiuchi T, Suda T: Caspase-1 Protein Induces Apoptosisassociated Speck-like Protein Containing a Caspase Recruitment Domain (ASC)-mediated Necrosis Independently of Its Catalytic Activity. J Bio Chem 2011;286:33963-33972.

64 Sozen T, Tsuchiyama R, Hasegawa Y, Suzuki H, Jadhav V, Nishizawa S, Zhang JH: Role of Interleukin-1 $\beta$ in Early Brain Injury after Subarachnoid Hemorrhage in Mice. Stroke 2009;40:2519-2525.

65 Calzadilla Bertot L, Adams LA: The Natural Course of Non-Alcoholic Fatty Liver Disease. Int J Mol Sci 2016;17:774. 